\title{
Fulles d'herba en el sistema literari català
}

\section{Leaves of Grass on the Catalan literary system}

\author{
Lourdes Frasquet \\ Universitat Jaume I \\ lourdesfrasquetporta@gmail.com
}

Data de recepció: 25/03/2018

Data d'aceptació: 31/01/2019

\section{Resum}

Si entenem que l'activitat traductora forma part del sistema literari que l'acull, tal com postulaven els seguidors de l'escola de la manipulació, no podem destriar la descripció de traduccions de l'enfocament històric. Aquest article es proposa observar com la llengua de la literatura traduïda varia amb el temps i, més concretament, com ho fa la del sistema literari català dels segles XX i XXI. Per tal d'assolir aquests objectius, s'hi proposa una anàlisi comparativa entre dues traduccions al català de Fulles d'herba de Walt Whitman, inscrites en períodes històrics molt diferents: la primera, modernista, a càrrec de Cebrià de Montoliu, de l'any 1909; la més recent, de 2014, efectuada per Jaume C. Pons Alorda.

Paraules clau: literatura traduïda; polisistema; Fulles d'herba; Cebrià de Montoliu; Jaume C. Pons Alorda.

\begin{abstract}
According to the Manipulation School, translation is conceived as a part of the target literary system. Therefore, translation description cannot be separated from the historical setting. This paper aims to observe how language in translated literature changes over time and, specifically, how Catalan language does it during the 20th and the 21 st centuries. To achieve theseaims, a comparative analysis between two different translations into Catalan of Walt Whitman's Leaves of Grass has been proposed. These translations were published in two different historical moments: the first one was translated in 1909, in the Modernist period, by Cebrià de Montoliu; the most recent one, in 2014, a work done by Jaume C. Pons Alorda.
\end{abstract}

Key Words: translated literature; polysystem; Leaves of Grass; Cebrià de Montoliu; Jaume C. Pons Alorda. 



\section{Taula de continguts}

1. Qüestions prèvies: l'escola de la manipulació, un paradigma vigent

2. El sistema literari català dels segles XX i XXI: com hi encaixa Fulles d'herba?

3. Anàlisi comparativa de les traduccions de Fulles d'herba en el seu context

3.1 La forma externa: el tractament del ritme

3.2. La sintaxi

3.3. La modalitat

3.4. El lèxic

3.5. L'ús de paratexts

3.6. La ideologia de l'autor

4. Conclusions

Bibliografia 



\section{Qüestions prèvies: l'escola de la manipulació, un paradigma vigent}

Si parem atenció a la literatura traduïda, podrem acostar-nos al context sociocultural del període en què les traduccions van ser concebudes, així com entendre una mica millor les circumstàncies de recepció d'aquestes $\mathrm{o}$, fins i tot, la funció que acomplien en el sistema literari meta.

Aquest estudi pretén observar quins canvis s'han produït al llarg dels darrers segles en la literatura traduïda al català i en quina mesura el context de recepció hi ha influït. El nostre treball parteix d'una anàlisi comparativa en context de dues traduccions d'un mateix original: Fulles d'herba de Walt Whitman en les seues versions en català de Cebrià de Montoliu, de 1909, i de Jaume C. Pons Alorda de 2014.

L'anàlisi proposada se sustenta sobre el paradigma de l'Escola de la Manipulació, també conegut com a teoria dels polisistemes, l'aparició del qual, a meitat de la dècada dels 70 del segle XX, marca un abans i un després en els estudis de traducció. En línies generals, els autors del polisistema comparteixen «la voluntat d'acostar l'estudi de la traducció literària al mètode científic» (Marco, 2000: 30), motiu pel qual rebutgen l'orientació prescriptiva tradicional dels estudis de traducció, i s'inclinen més cap a una postura descriptiva. En Descriptive Translation Studies and Beyond (1995) Gideon Toury subratlla la importància de comptar amb una branca descriptiva en les disciplines empíriques, en tant que permet cartografiar els elements que conformen la parcel·la de la realitat que s'estudia.

Aspectes com l'enfocament històric i el concepte de norma són centrals en aquest paradigma: es considera que l'activitat traductora forma part del sistema literari receptor, fet que explica per què les traduccions es regeixen per les normes que estan en vigor en el context espacio-temporal en què s'inscriuen (Marco, 2002). Autors com André Lefevère (1992), però, van un pas més enllà en concebre la traducció com una forma de reescriptura: afirma que els traductors són autors amb criteri propi i que, per tant, com qualsevol altre escriptor, actuen a partir de les convencions ideològiques i formals voluntàriament assumides per la seua tradició cultural. 
A més, les traduccions tenen un caràcter funcional, és a dir, en el sistema meta acompleixen una funció més o menys central segons les circumstàncies particulars de recepció (Marco, 2002: 28-29). Per exemple, en el sistema literari català, la traducció ha esdevingut un mitjà de fixació del model de llengua en períodes com el Modernisme o el Noucentisme, tal com apunten Sellent (1998: 24) i Marco (2000: 31-32). Si hui en dia la traducció, en aquest mateix sistema, ha perdut la centralitat que podia tenir en aquella època és només perquè el sistema literari català està més consolidat i gaudeix de certa normalitat. Per als autors del polisitema, però, que la traducció tinga un paper secundari és símptoma de normalitat.

Paga la pena subratllar que, actualment, els estudis de traducció s'han acostat als estudis culturals i han evolucionat cap a altres paradigmes (deconstructivista, postcolonial o de gènere). Tot i això, entenem que la importància de l'escola de la manipulació és tan rellevant que, com va predir Marco (2002: 37), una bona part dels seus postulats no han esdevingut obsolets, sinó una part integral dels estudis de traducció i, justament per aquest motiu,resulten pertinents per sustentar la base teòrica d'aquest estudi.

\section{El sistema literari català dels segles XX i XXI: com hi encaixa Fulles d'herba?}

Segons Ferran Toutain (1997: 63), la funció de les traduccions cobra major importància en cultures amb tradició feble o interrompuda. És justament aquesta afirmació la que ens permet entendre per què des d'una perspectiva polisistèmica el sistema literari català dels darrers segles resulta tan interessant.

Tot i que les traduccions duien segles influint sobre la llengua literària catalana, caldrà esperar fins al Modernisme perquè la traducció literària esdevinga un espai central en l'afany de redreçament cultural català (Pericay i Toutain, 1996: 249). El moviment modernista es va caracteritzar essencialment per «la voluntat de trencar amb una concepció tradicionalista $\mathrm{i}$ regionalista de la cultura catalana, de transformar aquesta cultura en una cultura nacional i moderna» (Marfany, 1982: 16). Efectivament, l'activitat traductora d'aquest període té com a objectiu dotar el català de recursos perquè evolucione cap a una literatura moderna: era necessari, 
doncs, assimilar la complexitat estilística que havien aconseguit prèviament i de manera més lenta la resta de llengües europees (Pericay i Toutain, 1996: 256) i la millor manera d'aconseguir-ho era a través de la traducció. La literatura traduïda d'aquest període es caracteritza per l'heterogeneïtat estilística, la majoria de títols són publicats per la Biblioteca Popular de l’Avenç (ibíd.), entitat encarregada de traure a la llum per primera vegada en català Fulles d'herba de Walt Whitman, l'any 1909 de la ploma del mallorquí Cebrià de Montoliu.

La publicació de Leaves of Grass als Estats Units d'Amèrica el 1855 arriba envoltada de controvèrsia en una societat tan puritana com l'estatunidenca de l'època: Whitman trenca amb tota convenció mètrica vigent fins el moment; al·ludeix explícitament al sexe en els seus poemes i, a més, empra la llengua col·loquial anglesa del moment. Per damunt de tot, però, Leaves of Grass és un cant al nou ordre, a la nova democràcia o, com ell l'anomenava, «the good cause», i al seu país, els Estats Units, que ell considerava el paradigma de nació moderna. Així, no costa entendre per què, 54 anys després de la publicació, es decideix traduir al català aquesta obra: 1'esperit de Whitman i la seua obra encaixen a la perfecció amb les aspiracions nacionals i renovadores del corrent modernista. Així mateix ho justifica Montoliu (Montoliu en Whitman, 1909: 5):

Voleu aspirar d'una glopada la triple essencia de l'ideal novell, aquest nou somni d'industrialisme intens i democratic, d'exaltació nacional i germanor universal, que, procedent de les brumes barbres, ha vingut a desvetllar-vos, oh catalans, del vostre secular encantament migeval amb tant forta sotragada que la vostra vida social seriament ne perilla? Llegiu Walt Whitman.

Montoliu no realitza, però, una traducció íntegra de l'obra, sinó que recull els 23 poemes que considera més representatius. Cal esperar fins l'any 2014 per obtenir, de la mà d'un altre mallorquí, l'escriptor, poeta i traductor Jaume C. Pons Alorda, la traducció íntegra al català de Leaves of Grass. L'absència del bard de West Hills al sistema literari català entre 1909 i 2014 és gairebé total, llevat, d'algunes traduccions puntuals dels seus poemes més destacats efectuades per Agustí Bartra, l’any 1951, o per Josep Costa el 1992.

Aquesta absència pot explicar-se per diversos motius: en primer 1loc, pel context sociopolític que es viu a l'Estat espanyol durant una bona part del segle XX, en què evidentment 
la producció literària en llengua catalana minva substancialment; però també trobem una raó de la desaparició de Whitman en català amb l'arribada del Noucentisme. No és que amb aquest moviment l'activitat traductora es deixe de banda dins el sistema literari català; ben al contrari, la centralitat de la traducció es referma; tanmateix, segons Marfany (1982: 14), el Noucentisme va presentar-se com a creació i tot allò que el precedia, com a caos. Aquesta postura implicava la liquidació dels moviments anteriors, cosa que comporta també oblidar algunes obres i autors traduïts durant aquests períodes. En el cas d'un autor tan trencador com Whitman, cal sumar-hi la incompatibilitat ideològica amb un moviment com el noucentista, d'essència conservadora i amb voluntat de classicisme.

Per una altra banda, hi ha hagut durant molts anys en el sistema literari català una percepció negativa de les segones traduccions, com un esforç innecessari, o fins i tot com una impertinència si la primera traducció era obra d'un autor reconegut (Sellent, 1998: 30). Podem pensar que l'absència de Whitman també es deu a aquest darrer fet. Sembla, però, que amb el pas dels anys, sobretot a partir de finals del segle passat, es produeix un canvi substancial i aquella percepció a dia de hui gairebé ha desaparegut.

Així, arribem al 2014, any en què apareix una segona traducció de Leaves of Grass: aquesta vegada íntegra i amb propòsits molt distints de la primera. En un sistema literari amb certa consolidació, Jaume C. Pons Alorda i Edicions 1984 pretenen construir ponts mitjançant la traducció per salvar les barreres lingüístiques i culturals que separen Whitman de la societat catalanoparlant actual. Es tracta, si més no, de posar a l'abast dels lectors en català una obra tan cabdal dins la literatura universal com ho és Leaves of Grass. Així mateix, hi ha motius concrets que duen Pons Alorda a portar l'esperit whitmanià al context sociocultural català del segle XXI (2015: 2):

Aquest llibre, doncs, va néixer com a cant d'un nou país naixent que necessitava els seus poetes, artistes de la vida, per immortalitzar-la de forma èpica i, al mateix temps, aplicable a una nova ciutadania, delerosa de canvi i de millores substancials. 


\section{Anàlisi comparativa de les traduccions de Fulles d'herba en el seu context}

Una vegada contextualitzades les circumstàncies de recepció de cadascuna de les traduccions objecte d'aquest estudi, en presentem tot seguit l'anàlisi comparativa. Paga la pena assenyalar que l'anàlisi s'ha centrat únicament en tres poemes: «One’s Self I Sing», «City of Ships» $\mathrm{i}$ «A Woman Waits for Me». Com que la tasca de comparar les traduccions completes era, a més de titànica, impossible de realitzar en el marc del present estudi, hem escollit els tres poemes esmentats per la seua representativitat. Al llarg de l'anàlisi, l'original s'ha mantingut en tot moment únicament com a punt de referència, ja que el nostre objectiu no és la comparació exhaustiva de les traduccions amb l'original, sinó la comparació de les dues traduccions entre si.

Abans d'endinsar-nos, però, en aspectes més concrets de la comparació entre ambdues traduccions, és important subratllar que l'anàlisi s'ha realitzat de manera inductiva. Tot i això, el model d'anàlisi textual proposat per Josep Marco a El fil d'Ariadna (2002) ens ha servit de referència durant la realització del nostre treball, per la idoneïtat en l'anàlisi comparativa entre traduccions.

Tot seguit presentem els aspectes analitzats que hem considerat més rellevants, des dels punts de vista formal i lingüístic, així com traductològic.

\subsection{La forma externa: el tractament del ritme}

L'escriptura de Whitman, considerat el pare del vers lliure, es caracteritza per l'absència d'una forma establerta: no hi ha mètrica, ni rima. En Leaves of Grass podem observar com cada vers té un nombre de síl·labes distint que no atén a cap patró. Tanmateix, un dels aspectes que més caracteritza aquesta obra és justament el ritme. Tot i no haver-hi un esquema rítmic establert i regular, el ritme apareix sustentat principalment en repeticions i paral·lelismes. Així ho explica el mateix Montoliu (Montoliu en Whitman, 1909: 11):

[...] un vers lliure, ben lliure, tant, que deixa de ser vers; ritme n'hi ha, però, més que fonètic, ideologic; ritme d'idees, conceptes, imatges, més que de silabes [...] els paralelismes, les aliteracions, la rítmica successió 
d'articulades clausules en llargs periodes oratoris, donen al seu estil una cadenciositat ideal que supleix la feblesa del ritme sonor.

Conscients de la importància d'aquests tipus de recursos en l'obra original, tant Pons Alorda com Montoliu busquen reflectir-los en les seues respectives traduccions, tal i com podem observar a continuació:

\section{Versos 9 i 10}

Whitman Without shame the man I like knows and avows the deliciousness of his sex,

Without shame the woman I like knows and avows hers. ${ }^{1}$

Montoliu Sense vergonya l'home que $m$ m plau coneix i con fessa les delícies des del seu sexe, Sense vergonya la dòna que $\cdot \mathrm{m}$ plau coneix $\mathrm{i}$ confessa les seves ${ }^{2}$.

Pons Alorda Sense vergonya l'home que m'agrada sap i confessa les delícies del seu sexe,

Sense vergonya la dona que m'agrada sap i confessa les delícies del seu. $3^{3}$

\section{Versos 13 i 14}

Whitman I see that they understand me and do not deny me, I see that they are worthy of me [...]

Montoliu Jo veig que elles m'entenen i no'm neguen, Jo veig que són dignes de mi [...]

Pons Alorda Jo veig que m'entenen i que no em rebutgen, Jo veig que són dignes de mi [...]

Vers 32

Whitman On you I graft the grafts $[\ldots]$

Montoliu En vós jo empelto $\cdot$ ls empelts $[\ldots]$

Pons Alorda En vosaltres empelto els empelts [...]

Hi ha ocasions, però, en què mantenir determinats recursos no és possible. Per exemple, a la primera estrofa d'«A Woman Waits for Me», les repeticions de l'original apareixen en ambdues

$1 \quad$ Les cites de Leaves of Grass han estat extretes de Whitman, Walt (1990). Leaves of Grass. Oxford University Press, Oxford.

2 Les cites de la traducció de Cebrià de Montoliu han estat extretes de Whitman, Walt (1909). Fulles d'herba. Biblioteca Popular de l'Avenç, Barcelona.

3 Les cites de la traducció de Jaume C. Pons Alorda han estatextretesde Whitman, Walt (2014). Fulles d'herba. Barcelona: Edicions 1984. 
traduccions com a repeticions amb variació, la qual deriva de les divergències morfològiques entre la llengua origen i la d'arribada:

\title{
Versos 1 i 2
}

\author{
Whitman A woman waits for me, she contains all, nothing is lacking, \\ Yet all were lacking if sex were lacking, or if the moisture of the \\ right man were lacking. \\ Montoliu Una dòna m'espera, tot ho conté, res li manca, \\ Més tot mancaria si $\cdot 1$ sexe mancava, o si manca- \\ va'l llevat de l'home bo. \\ Pons Alorda Una dona m'espera, té a dins totes les coses, no existeix res que li \\ falti, \\ Però tot li faltaria si li faltés el sexe, o si li faltés el suc de l'home \\ bo.
}

En aquest cas no és possible mantenir la repetició total perquè la morfosintaxi verbal és diferents en una llengua i l'altra: mentre que l'anglés repeteix la mateixa forma verbal, el gerundi (lacking), en català s'empra el mateix lexema, però amb diverses formes com ara, condicionals (mancaria, faltaria), imperfets d'indicatiu (mancava) o de subjuntiu (faltés).

El ritme determinarà també certes decisions lèxiques. Per exemple, en «A Woman Waits for Me», Whitman empra les enumeracions com a punt de suport del ritme i ambdós traductors els mantenen en els seus respectius treballs. Des d'un punt de vista lingüístic, en aquestes enumeracions apareix una gran quantitat de lèxic que varia d'una traducció a l'altra. Concretament, en aquests fragments, trobem un recurs utilitzat per Pons Alorda que crida l'atenció: la utilització de més d'un mot per traduir-ne un de sol en anglés. Observem-ne uns exemples:

Versos 8 i 9

$\begin{array}{ll}\text { Whitman } & \begin{array}{l}\text { All hopes, benefactions, bestowals, all the passions, loves, } \\ \text { beauties, delights of the earth }[\ldots]\end{array} \\ \text { Montoliu } & \begin{array}{l}\text { Totes les esperances, benifets, favors, totes les } \\ \text { passions, amors, belleses, delícies del món, }[\ldots]\end{array} \\ \text { Pons Alorda } & \begin{array}{l}\text { Totes les esperances, accions benefactors, favors, dons gràcies, to- } \\ \text { tes les passions, amors, belleses, delits del món, }[\ldots]\end{array}\end{array}$

Versos 29 i 30

Whitman They are ultimate in their own right--they are calm, clear, well-possess'd of themselves.

Montoliu Són absolutes en llurs drets - són calmes, franques, mestresses de sí mateixes. 
Pons Alorda Són absolutes i inexorables en el seu propi dret — són serenes, sinceres, segures d'elles mateixes.

Versos 38 i 39

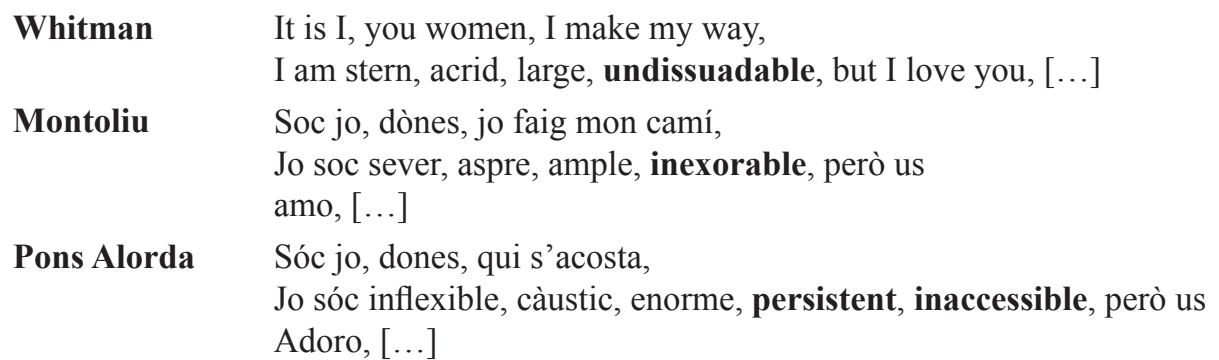

En tots tres casos, Pons Alorda ha volgut transmetre el significat complet del mot original en anglés i, com que considera que amb un sol mot l'equivalència semàntica no és del tot completa, opta per utilitzar-ne més d'una. Cal remarcar que aquest recurs és arriscat, ja que no sempre funciona. En aquest cas, però, és una bona solució perquè es tracta d'un poema escrit en vers lliure i, més concretament, perquè l'adjectiu traduït es troba enmig d'una enumeració.

En «City of Ships», hi trobem un exemple en què el ritme determina la diferència de lèxic d'ambdues traduccions:

Versos 2 i 3

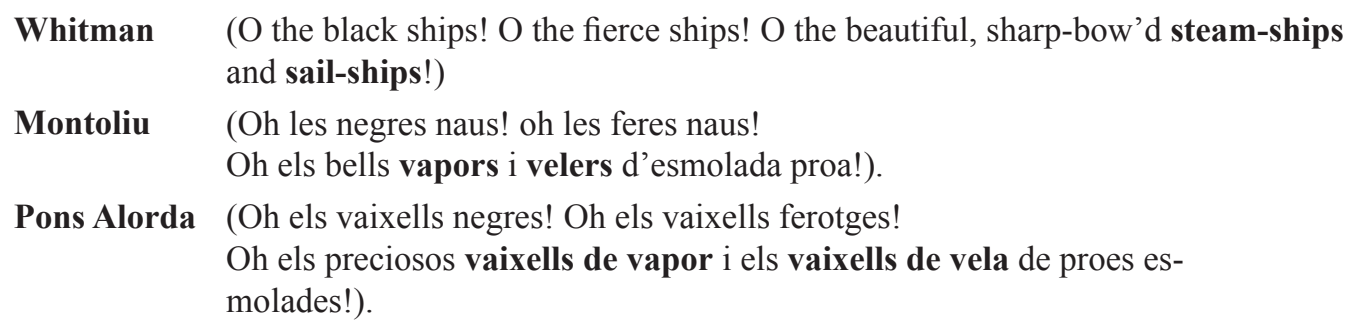

En aquest cas, cal assenyalar que la formació del lèxic en anglés és distinta a la del català: els dos mots emprats per Whitman són paraules compostes (substantiu+substantiu); en català, però, comptem amb mots d'una sola arrel lèxica per a referir-nos al mateix concepte (en aquest cas vapors i velers), dels quals se serveix de Montoliu en la seua traducció. A primera vista, podríem considerar més adequada, per genuïnitat, aquesta opció; tanmateix, com que es tracta d'un poema, hem d'atendre també el ritme. Potser aquesta darrera raó explica per què Pons Alorda opta pels compostos sintagmàtics vaixells + complement preposicional, prioritzant la creació de ritme en la traducció, tot i que el resultat siga una mica diferent del de l'original. 


\subsection{La sintaxi}

Pel que fa als aspectes sintàctics, en línies generals Montoliu sembla acostar-se més a l'original, fet que sovint propicia calcs; Pons Alorda, per la seua banda, és més proper a la sintaxi i gramàtica catalanes. Tot i això, de vegades, Montoliu escapa al calc i, en acostar-se a l'original, adopta molt bones solucions, com ocorre en «One's Self I Sing». En aquest poema en concret, l'eix rítmic el constitueix l'estructura següent:

\begin{tabular}{|c|c|}
\hline $\begin{array}{l}\text { One's self } \\
\text { objecte }\end{array}$ & $\begin{array}{c}\text { I } \\
\text { subjecte }\end{array}$ \\
\hline
\end{tabular}

Ja en l'original, Whitman opta per una sintaxi molt marcada en aquesta oració, la qual es repeteix al llarg de tot el poema i es converteix en el pilar que sustenta el ritme. Ambdós traductors respecten i transmeten el paral·lelisme, un dels trets més característics del poeta, però sintàcticament opten per solucions distintes.

D’una banda, Montoliu manté l'estructura marcada, tal com ho fa Whitman:

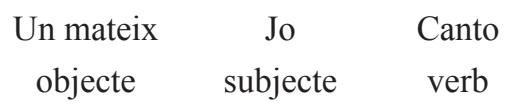

Mentre que Pons Alorda, de l'altra, n'utilitza una de més propera a l'ordre habitual en català:

$$
\begin{array}{ccc}
\text { Jo } & (\mathrm{em}) \text { canto } & \text { a mi mateix } \\
\text { subjecte } & \text { verb } & \text { objecte }
\end{array}
$$

Tots dos mantenen la mateixa solució al llarg del poema sencer:

\begin{tabular}{l|ll} 
& Montoliu & Pons Alorda \\
\cline { 2 - 3 } Vers 1 & Un mateix jo canto & Jo em canto a mi mateix \\
Vers 3 & De fisiologia de cap a peus jo canto & Jo canto la fisiologia de cap a peus \\
Vers 6 & La Femella igual que·1 Mascle canto & Jo canto la Dona ben igual que l'Home \\
Vers 9 & L'Home Modern jo canto & Jo canto l'Home Modern
\end{tabular}

L'opció de Montoliu sembla més arriscada en català, ja que l'estructura dista molt de la sintaxi que habitualment hi emprem. Whitman, però, fa el mateix amb l'original, ja que l'ordre sintàctic en anglés tendeix a ser subjecte + verb + objecte, el qual, siga dit de pas, és molt més rígid que el català. Per tant, encara que arriscada, l'elecció de Montoliu és del tot encertada en 
aquest cas, ja que manté un ordre que ja era marcat en l'original. Per la seua banda, Pons Alorda reorganitza la sintaxi de manera que s'ajusta més a l'ordre natural català.

Tanmateix, també hi trobem casos en què seria més convenient decantar-nos per l'acostament a la llengua d'arribada. Un exemple ben clar és la traducció de l'estructura anglesa adjectiu + substantiu, que, al contrari que en el cas anterior, no té un ordre marcat en l'original: en anglés sempre s'anteposa l'adjectiu al substantiu. Així, caldria traslladar-la al català de la mateixa manera: com una estructura no marcada. A través dels exemples següents extrets de «One's Self I Sing», veiem com Montoliu empra una estructura marcada en català que hi resulta poc natural, mentre que Pons Alorda s'acosta més a la sintaxi de la llengua meta:

\begin{tabular}{lll} 
Whitman & Montoliu & Pons Alorda \\
\hline a simple & una simple & una persona \\
separate & i distinta & senzilla i \\
person & persona & independent
\end{tabular}

El mateix ocorre en «City of Ships»:

\begin{tabular}{l|l} 
Vers 2 & $\begin{array}{l}\text { Whitman } \\
\text { O the black ships ! O the fierce ships ! } \\
\text { Montoliu } \\
\text { Oh les negres naus! Oh les feres naus! } \\
\text { Pons Alorda } \\
\text { Oh els vaixells negres! Oh els vaixells ferotges! } \\
\text { Wers } 6\end{array}$ \\
$\begin{array}{l}\text { Whitman } \\
{[\ldots] \text { City of hurried and glittering tides ! }} \\
\text { Montoliu } \\
{[\ldots] \text { Ciudad de rapides i fulgides marors! }} \\
\text { Pons Alorda } \\
{[\ldots . .] \text { Ciutat de marees violentes i resplendents! }}\end{array}$
\end{tabular}

En canvi, trobem casos en aquest mateix poema en què Pons Alorda manté l'ordre anglés, mentre que Montoliu s'acosta més a la sintaxi catalana: 


\begin{tabular}{l|lll} 
& Whitman & Montoliu & Pons Alorda \\
\cline { 2 - 4 } Vers 9 & $\begin{array}{l}\text { Proud and passionate } \\
\text { city }\end{array}$ & $\begin{array}{l}\text { Ciutat soperba } \mathrm{i} \\
\text { passionada }\end{array}$ & $\begin{array}{l}\text { Orgullosa i apassionada } \\
\text { ciutat }\end{array}$ \\
Vers 17 & War, red war $[\ldots]$ & $\begin{array}{l}\text { Guerra, la guerra } \\
\text { vermella }[. . .]\end{array}$ & $\begin{array}{l}\text { La guerra, la vermella } \\
\text { guerra }[\ldots]\end{array}$
\end{tabular}

En el segon cas, podem observar com Pons Alorda és més pròxim a l'estructura i ritmes originals (guerra $+a d j .+$ guerra $)$ en detriment d'un ordre sintàctic més propi del català, al contrari que Montoliu.

En «A Woman Waits for Me» trobem un exemple de l'estructura anglesa adjectiu + adjectiu + nom:

\begin{tabular}{lll} 
Whitman & Montoliu & Pons Alorda \\
\hline The old divine & La vella divinal & L’antiga agilitat i força \\
suppleness and strength & suplesa i força & divines
\end{tabular}

Montoliu cau de nou en el calc; a més, amb el lèxic que utilitza (divinal en lloc de divina) contribueix al to arcaic que caracteritza la llengua literària de l'època. Pons Alorda, en canvi, pren una decisió que podríem considerar més adequada davant d'aquest tipus d'estructures: anteposar un adjectiu al nom i posposar l'altre. Tanmateix, no se n'acaba de sortir del tot, perquè en anglés old divine modifiquen tant suppleness com strength, mentre que en català antiga sembla afectar només el substantiu més pròxim (agilitat), encara que res no impedeix sintàcticament que modifique els dos noms coordinats.

\subsection{La modalitat}

La modalitat és un altre dels aspectes gramaticals en què ambdues traduccions difereixen. Observem-ne un exemple extret de «A Woman Waits for Me»:

\begin{tabular}{lll} 
Whitman & Montoliu & Pons Alorda \\
\hline $\begin{array}{l}\text { «[..] I will be the } \\
\text { robust husband of } \\
\text { thosewomen }[\ldots] »\end{array}$ & $\begin{array}{l}\text { «[...] jo vull ser } \\
\text { el robust espòs }\end{array}$ & $\begin{array}{l}\text { d'aquelles dònes }[\ldots] » \\
\text { robust d'aquestes } \\
\text { dones }[\ldots] »\end{array}$ \\
$\begin{array}{lll}\text { «Now I will dismiss } \\
\text { myself }[\ldots] »\end{array}$ & «Ara.m vull apartar & «Ara mateix em faré \\
& {$[\ldots] »$} & fora $[\ldots] »$
\end{tabular}




$\begin{array}{ll}\text { «I would do you } & \text { «Jo us voldria fer bé } \quad \text { «Jo us faré bé }[\ldots] » \\ \operatorname{good}[\ldots] » & {[\ldots] »}\end{array}$

Originalment, will indica voluntat; tanmateix, amb el pas del temps s'ha gramaticalitzat fins a esdevindre un verb modal que indica futur. D'acord amb això, ambdues opcions són acceptables, ja que Montoliu recull la connotació de voluntat, mentre que Pons Alorda la de temporalitat futura. Tanmateix, si parem una mica més d'atenció al poema original, observem com Whitman empra un altre modal de futur, shall: és molt possible que empre aquest modal per a parlar en futur i que utilitze will per a indicar voluntat. Des d'aquest punt de vista, l'opció de Montoliu podria ser més acurada pel que fa al sentit original que hi vol donar l'autor.

En el cas de would, Alorda continua emprant el futur encara que ací no es corresponga amb l'original, mentre que Montoliu sí que ha mantingut tant la modalitat condicional com el sentit de voluntat.

\subsection{El lèxic}

Com ja hem esmentat, una traducció, en tant que activitat que forma part del sistema literari de la llengua d'arribada, s'ajusta a les normes en vigor d'aquest sistema. Això s'observa especialment en els aspectes lèxics, a causa de les decisions d'un traductor i l'altre. Per això, és parant atenció a aquests aspectes com millor podem adonar-nos de les diferències entre ambdues traduccions.

El cas de Montoliu és especialment remarcable, ja que la seua traducció transmet una sensació arcaïtzant, mitjançant la utilització del possessiu llur, del verb plaure en comptes de agradar (per l'original to like) o el pronom personal vós, entre altres recursos. Aquest to deliberadament arcaic respon a una qüestió de gustos de l'època que conformen l'estil modernista; gustos, siga dit de pas, que més tard heretaran els noucentistes i que tant influiran en el seu model de llengua. De fet, paga la pena assenyalar que, en el cas de les traduccions de Montoliu, aquest arcaisme és encara més acusat que en els treballs dels seus coetanis: en les traduccions d'aquest encara es conserven ecos de la Renaixença (Pericay i Toutain, 1996). 
Un bon exemple d'aquest to arcaic el trobem en la traducció de Montoliu de «A Woman

Waits for Me» per l'ús del pronom personal vós:

Vers 22

\author{
Whitman \\ I am for you, and you are for me, not only for our own sake, but for others' \\ sakes, $[\ldots]$ \\ Montoliu \\ Jo soc per a vós, i vós sou per a mi, no solament per mor nostres, més per mor \\ d'altres $[\ldots]$ \\ Pons Alorda \\ Jo sóc vostre i vosaltres sou meves, i ho som pel nostre bé i pel bé dels altres, \\ $[\ldots]$
}

Versos 32, 33, 34 i 35
Whitman
In you I wrap a thousand onward years,
On you I graft the grafts of the best-beloved of me and America,
The drops I distill upon you shall grow fierce and Athletic girls, new artists, musicians, and singers,
The babes I be get upon you are to be get babes in their turn $[\ldots]$

\section{Montoliu}
En vós jo envolco un miler d'anys a venir,
En vós jo empelto·ls empelts dels predilectes meus i d'America,
Les gotes que en vós destil·lo criaran braves i atlètiques dònes, nous artistes, musics i cantors,
Els nins que en vós jo engendro han d'engendrar nins al llur torn [...]
Pons Alorda
Dins vosaltres compilo un miler d'anys futurs,
En vosaltres empelto els empelts del que més estimo i d'Amèrica,
Les gotes que en vosaltres destil·lo criaran nenes ferotges i atlètiques, nous artistes, músics i cantants,
Els infants que en vosaltres engendro també engendraran infants quan sigui el seu torn, $[\ldots]$

Si bé you pot tenir diverses equivalències en català (tu, vosaltres, vosté, vostès $i$ vós), en aquest cas concret, vós i vosaltres representen dos exponents de dos moments diferents des d'una perspectiva diacrònica en el sistema literari de recepció: el de la Renaixença-Modernisme, d'una banda, i el contemporani, de l'altra.Justament aquestes diferències lèxiques són les que ens ajuden a determinar el canvi estilístic que es produeix entre una traducció i una altra.

Sense abandonar l'enfocament històric, tot seguit ens detindrem en un parell d'exemples extrets del poema «A Woman Waits for Me». Aquest és un dels poemes que millor encarna l'esperit whitmanià de trencament, pel que fa a la forma externa, però sobretot per la temàtica. Tot i que hui en dia l'aspecte temàtic considerat més escandalós de tota la producció del poeta 
són les seues al·lusions a l'homosexualitat, en ple segle XIX el focus d'atenció se centrava en aquells poemes que feien referència a relacions heterosexuals, la majoria dels quals s'inclouen dins l'aplec titulat «Children of Adam», on podem trobar el poema que ens ocupa. «A Woman Waits for Me», originalment titulat «Poem of Procreation», descriu la unió a través del sexe entre un home i una dona que culminarà amb la fertilització i la fecundació de: sons and daughters fit for these States, això és, de la descendència ideal per a una nació moderna com ho eren els Estats Units per a Whitman. Un altre tret característic de Whitman és l'actitud igualitària entre ambdós gèneres, que apareix reflectida al llarg de tot el poema: equipara l'home amb la dona i, fins i tot, qualifica aquesta de fierce and athletic, adjectius que tradicionalment no s'han associat al gènere femení.

Veiem, però, com un traductor i l'altre aborden la traducció d'aquest poema amb un grau d'explicitació distint:

\begin{tabular}{lll} 
Whitman & Montoliu & Pons Alorda \\
\hline Interpenetrate & Compenetrar & Penetrar \\
(are) sufficient for me & Em satisfan & Tant de plaer em donen
\end{tabular}

Com bé podem observar en el primer exemple, tot i compartir la mateixa arrel i pràcticament el mateix sentit, el verb emprat per Pons Alorda és molt més explícit sexualment que l'escollit per Montoliu. En el segon cas, de nou, la traducció més recent és més explícita. En ambdós casos, però, sembla fins i tot que Pons Alorda vaja un pas més enllà que el propi Whitman quant a explicitació, sobretot en el cas de sufficient on parlar de tant de plaer seria desviar-se una mica de l'original. Per explicar aquestes diferències ens hem de remetre, una vegada més, al context en què s'inscriuen una traducció i l'altra.

De la mateixa manera que ocorre amb els aspectes sintàctics anteriorment esmentats, hi ha moments en què l'acostament excessiu de Montoliu al text original el fa caure en opcions massa marcades o, fins i tot, en calcs lèxics, com podem observar en els exemples següents:

\begin{tabular}{lll} 
Whitman & Montoliu & Pons Alorda \\
\hline Female and Male & Mascle i Femella & Dona i Home
\end{tabular}


En anglés, la parella lèxica male/female s'aplica a humans més sovint que mascle/ femella en català, els quals s'empren quan fem referència a animals. Per això, en aquesta ocasió és més adequat utilitzar dona/home. Veiem com Montoliu escull l'opció més marcada, perquè,des de la perspectiva morfolèxica, s'acosta més a l'original. Pons Alorda, però, opta per Dona i Home, molt més adequat semànticament i pragmàticament en aquest cas. En el cas següent ocorre una situació semblant:

\begin{tabular}{lll} 
Whitman & Montoliu & Pons Alorda \\
\hline Pulse & Pulsació & Impuls
\end{tabular}

Montoliu opta per una forma molt més pròxima a l'anglesa externament, però que no hi equival semànticament. En aquesta tria, podríem pensar que entra en joc un altre factor que va més enllà del lèxic: l'al·literació de l'original. Al vers 6 Whitman utilitza tres paraules que comencen per la lletra $p$ :

«Of Life immense in passion, pulse and power.»

Potser, això justificaria que Montoliu es decantara per la utilització de pulsació; descartem de seguida aquesta possibilitat quan veiem que power ha estat traduït per força. Per la seua banda, Pons Alorda empra una paraula més adient pel que fa al significat, però també perd l'al·literació de l'original.

Tanmateix, no és sempre Montoliu qui es desvia del sentit original, semànticament parlant; en l'exemple següent, observem no només que el lèxic utilitzat és diferent, sinó que a més el sentit és oposat:

\begin{tabular}{lll} 
Whitman & Montoliu & Pons Alorda \\
\hline Pent-up rivers & Closos rius & Desbordants rius
\end{tabular}

Mentre que els rius de Montoliu queden closos, els de Pons Alorda es desborden. Tenint en compte l'original, podríem qualificar de més encertada la primera opció, ja que pent-up vol dir que estan bloquejats, que troben el pas barrat, que no troben eixida. El que la imatge dóna a entendre és que finalment la veu poètica vessa aquell líquid que abans no trobava eixida, que 
estava comprimit, contingut. De fet, hi ha l'expressió pent-up emotion, que equival en català a emoció continguda i que, potser, finalment acaba fluint.

En altres ocasions, per tal d'entendre la diferència d'opcions lèxiques entre els dos traductors cal que remetem al sentit del text original, com observem en l'exemple següent extret de «City of Ships»:

\begin{tabular}{lll} 
Whitman & Montoliu & Pons Alorda \\
\hline Lands & Terres & Països
\end{tabular}

La Guerra de Secessió (1861-1865) és un dels eixos temàtics de la poètica whitmaniana i així queda reflectit en «City of Ships». El poema parla de Nova York, via d'entrada per a immigrants vinguts d'arreu del món, sobretot d'Europa, fet que dota la ciutat d'una diversitat social i cultural única que l'autor admira. A través dels seus poemes, Whitman exalta el nou ordre i la nova democràcia d'un nou país, els Estats Units, que comença a ser conscient del seu ésser i de la seua potència fins aquell moment sotmesa. Atenent, llavors, a aquest sentiment patriòtic i nacionalista de l'autor, seria una bona opció parlar de països com fa Pons Alorda. Tanmateix, de manera descontextualitzada i parant atenció a la semàntica, pot ser que terres, l'opció de Montoliu, siga un equivalent més directe.

\subsection{L'ús de paratexts}

Encara que a simple vista no ho puga semblar, la utilització de paratexts en les traduccions és una decisió important del procés. En aquest cas, és interessant destacar l'ús dels prefacis. Mentre que a la traducció de Pons Alorda no n'apareix cap, Montoliu hi adjunta a la seua una introducció de sis pàgines. La decisió d'incloure-hi o no una introducció resulta significativa, ja que si llegim el prefaci de Montoliu ens adonarem que, en realitat, es tracta de justificar la decisió de traduir Whitman (Montoliu en Whitman, 1909: 11)

Ja veieu amb això que no·s tracta de cap novetat literaria. Més si per la data pot calificar-se de vella, no així per la seva actualitat, que es més forta avui que mai, com passa amb tots els grans pensadors que s'han 
avençat al seu temps. Actual serà en tot cas per a nosaltres, que tant atraçats anem de cronologia ideal en vista les nacions que marquen l'hora del temps veritable.

Montoliu transmet clarament l'esperit modernista al llarg d'aquestes línies. Per la seua banda, Pons Alorda, respecte a no incloure cap paratext en la seua traducció, argumenta el següent (Pons Alorda en Abrams, 2015):

Quasi dos-cents anys després del seu naixement, volíem que els lectors arribessin a Whitman amb el mínim d'intermediaris possibles. [...] Jo crec que Whitman s'explica perfectament sense necessitat de paratextos.

La decisió d'incloure o no un prefaci, en aquesta ocasió, està completament lligada a la funció de la traducció en el context històric en què aquesta s'emmarca: mentre que a l'època modernista la traducció es veia com un mitjà de fixació de la llengua, un instrument per proporcionar al català els recursos per evolucionar cap a una literatura moderna i elevar la cultura catalana a l'esglaó de la universalitat, actualment, la traducció no es concep com una ferramenta per marcar o divulgar una norma, perquè, en paraules de Marco (2000:44), ja hi ha una literatura original normalitzada que se n'encarrega.

\subsection{La ideologia del traductor}

És una idea ja assentada en els estudis de traducció la concepció que tot aquell que tradueix intervé de forma conscient o inconscient en el text (Martínez Carrasco i Frasquet, 2015: 666). Si ens allunyem de plantejaments asèptics que afirmen que els traductors exerceixen un paper neutre de transvasament lingüístic, hi trobem autors, com Maria Tymozcko (2003) que arriben a afirmar que les traduccions mai no són fidels ni neutrals, sinó un acte deliberat de posicionament ideològic. De fet, el mateix Pons Alorda afirma el següent al respecte (Pons Alorda, 2015b):

[...] tots els traductors i totes les traductores tenen una veu, una possibilitat de veu que quedarà condicionada d'una manera o una altra. Una traducció objectiva no existeix, perquè passa per un fil conductor que és la persona, un ésser humà amb un passat (que és la història), amb un present (l'acte de traduir) i un futur (camí encara per recórrer). 
A més, en un context com l'actual a Catalunya, la tria de determinades paraules té uns ecos, unes ressonàncies indubtables, que fan que uns poemes escrits per un nord-americà del segle XIX es puguen llegir en clau catalana actual pel que fa a realitats polítiques com el procés sobiranista i la reivindicació d'una Catalunya independent. Els exemples següents ho il·lustren perfectament:

\begin{tabular}{lll} 
Whitman & Montoliu & Pons Alorda \\
\hline Freest & Lliure & Més sobirans \\
a simple separate person & una simple i distinta persona & una persona senzilla i independent
\end{tabular}

En el primer cas, Montoliu utilitza la forma lliure, que, deixant de banda que no respecta el superlatiu de l'original, semànticament és del tot equivalent. En canvi, Pons Alorda opta per més sobirans, de manera que transmet el superlatiu, però, a més, va un pas més enllà quant a la semàntica: la càrrega ideològica de la forma sobirà en el context sociopolític actual és innegable. El mateix ocorre amb el cas de separate, en què Montoliu utilitza un simple distinta, mentre que Pons Alorda es decanta per un independent. Aquests arguments es veuen reforçats per les declaracions del mateix Pons Alorda quan, explicant la bona recepció de Fulles d'herba en el context actual per a una entrevista en la revista digital Núvol, afirma el següent (Pons Alorda en Abrams, 2015):

[...] han influït molts factors [...] fins i tot, el fet sociològic actual de la possibilitat real de la independència de Catalunya. Whitman és l'autor d'un continent nou, el bard d'una nova nació que canta a la recerca d'un sentit poètic vital a aquest nou tot que comença. Per això dóna molta alegria, però sobretotil lusió i esperança.

\section{Conclusions}

Des d'un punt de vista polisistèmic, el sistema literari català dels segles XX i XXI resulta especialment interessant: a principis del segle XX, en ple modernisme, la traducció al català es concep com una via per arribar a ser una nació i una cultura universals, i, al mateix temps, com una ferramenta per omplir el buit dels segles precedents en la producció literària en la nostra llengua. Actualment, però, la centralitat que les traduccions podien ocupar a principis del segle passat en el nostre sistema literari s'ha perdut en detriment de certa normalització i 
consolidació; de fet, per als autors del marc teòric del polisistema, el paper secundari de les traduccions en un sistema és sinònim de la normalitat d'aquest.

Per això, a partir de l'anàlisi comparativa de les dues traduccions de Leaves of Grass, separades per més d'un segle de distància, podem concloure que tant l'estratègia global de traducció, com les decisions puntuals i, per extensió, el resultat final del procés venen determinades per les circumstàncies concretes de recepció en què s'inscriuen totes dues traduccions: el lloc que ocupen en el sistema literari d'acollida, la incidència de les normes d'aquest, la relació de poder establerta entre la literatura origen i la literatura meta (Montoliu, per exemple, concebia la cultura estatunidenca com el model a què havia d'aspirar la catalana) o, fins i tot, la persona que tradueix (la figura de l'escriptor consagrat traductor avui en dia no és tan habitual com podia ser-ho en èpoques anteriors).

Així, podem concloure que és erroni parlar de traduccions definitives, les quals, des d'un enfocament històric, no existeixen. Això desmuntaria un prejudici que, malgrat que sembla estar esvaint-se des de fa uns anys, s'ha mantingut durant molt de temps en la nostra cultura literària: les segones traduccions es consideren innecessàries. Com bé afirmava allà pel 1932 el qui fora traductor de Leaves of Grass al castellà, Jorge Luís Borges, «el concepto de texto definitivo no corresponde sino a la religión o al cansancio» (1932: 44). 


\section{Bibliografia}

Abrams, S. (2015). «Jaume C. Pons Alorda: Whitman en català enganxa de puta mare», en Núvol. Barcelona. Disponible a: $<$ https://www.nuvol.com/entrevistes/jaume-c-pons-alordawhitman-en-catala-enganxa-de-puta-mare/> [Última consulta: 24/03/18].

Bartra, A. (1951). Una antologia de la lírica nord-americana. Ciutat de Mèxic: Edicions Lletres.

Borges, J. L. (1932). Discusión. Buenos Aires: Ediciones Neperus.

Costa, J. (1992). Walt Whitman. Càlam/Calamus. Barcelona: Institut d'Estudis Nord-americans.

Lefevère, A. (1992). Translation, Rewrting and the Manipulation of Literary Fame. Londres: Routledge.

Marco, J. (2000). «Funció de les traduccions i models estilístics, el cas de la traducció al català del segle XX», en Quaderns. Revista de traducció, Volum 5, pp. 29-44.

Marco, J. (2002). El fil d'Ariadna. Anàlisi estilística i traducció literària. Vic: Eumo.

Marfany, J. L1. (1982). Aspectes del modernisme. Barcelona: Curial.

Martínez Carrasco, R. i Frasquet L. (2015). «Traducció, identitat i subversió. Reflexions cap a una praxi queer de la traducció», en Fòrum de recerca, Volum 20, pp. 665-670.

Pericay, X. i Toutain, F. (1996). El malentés del noucentisme. Barcelona: Proa.

Pons Alorda, J. C. (2015a). «Walt Whitman», en Visat, Volum 19. Disponible a: <http://www. visat.cat/literaturauniversalcatala/cat/autor/236/29/angles/walt-whitman.html> [Última consulta: $24 / 03 / 18]$.

Pons Alorda, J. C. (2015b). «Més enllà de la traducció de 'Fulles d'herba' de Walt Whitman», en 1611 Revista d'història de la traducció, Volum 9, Barcelona. 
Sellent, J. (1998). «La traducció literària al català al segle XX: alguns títols representatius», en Quaderns. Revista de traducció, Volum 2, Barcelona, pp. 23-32.

Toutain, F. (1997). «Traducció i models estilístics», en González, S. i Lafarga, F. (Ed.), Traducció i literatura. Homenatge a Ángel Crespo. Crespo, pp. 63-72. Vic: Eumo.

Toury, G. (1995). Descriptive Translation Studies and Beyond. Amsterdam/Filadèlfia: John Benjamin.

Tymozcko, M. (2003). «Ideology and the Position of the Translator: In what Sense Is Translator 'In-Between'?» en Calzada, M. (Ed.) Apropos of Ideology. Translation Studies on Ideology - Ideologies in Translation Studies, pp. 181-201. Manchester: St Jerome.

Whitman, W. (1990). Leaves of Grass. Oxford: Oxford University Press.

Whitman, W. (1909). Fulles d'herba. Montoliu, Cebrià (Trad.). Barcelona: Biblioteca Popular de l'Avenç.

Whitman, W. (2014). Fulles d'herba, Pons Alorda, Jaume C. (Trad.). Barcelona: Edicions 1984. 